\title{
Grazing of large-sized bacteria by sea-ice heterotrophic protists on the Mackenzie Shelf during the winter-spring transition
}

\author{
Andrea Riedel ${ }^{1,2, *}$, Christine Michel ${ }^{2}$, Michel Gosselin ${ }^{1}$ \\ ${ }^{1}$ Institut des sciences de la mer (ISMER), Université du Québec à Rimouski, 310 allée des Ursulines, Rimouski, \\ Québec G5L 3A1, Canada
}

${ }^{2}$ Fisheries and Oceans Canada, Freshwater Institute, 501 University Crescent, Winnipeg, Manitoba R3T 2N6, Canada

\begin{abstract}
Heterotrophic bacterial dynamics were assessed in the sea ice and surface waters on the Mackenzie Shelf (Beaufort Sea), from 5 March to 3 May 2004. On 11 occasions, heterotrophic protist bacterivory was assessed from the disappearance of fluorescently labeled bacteria (FLB) in sea-ice samples collected from areas of high and low snow cover. Concurrently, sea-ice and surface water samples were analyzed for dissolved organic carbon (DOC), exopolymeric substances (EPS) and chlorophyll a concentrations, and protist and bacterial abundances. Total bacterial abundances were significantly higher in the sea ice than in surface waters. However, DOC concentrations and abundances of large $(\geq 0.7 \mu \mathrm{m})$ bacteria were not significantly higher in the sea ice as compared to surface waters. This suggests that DOC was being released from the sea ice, potentially supporting the growth of large-sized bacteria at the ice-water interface. Heterotrophic protist (HP) bacterivory averaged $57 \% \mathrm{~d}^{-1}$ of large-sized bacterial abundances in the sea ice with ingestion rates averaging 768 and 441 bacteria $\mathrm{HP}^{-1} \mathrm{~d}^{-1}$, under high and low snow cover, respectively. High concentrations of EPS during the sea-ice algal bloom may have interfered with the grazing activities of heterotrophic protists as indicated by the significant negative correlations between ingestion rates and EPS-carbon concentrations under high $(\tau=-0.57, \mathrm{p}<0.05)$ and low $(\tau=-0.56, \mathrm{p}<0.05)$ snow cover. Bacterivory satisfied heterotrophic protist carbon requirements prior to, but not during, the sea-ice algal bloom, under high and low snow cover. EPS may have been an additional carbon source for the heterotrophs, especially during the sea-ice algal bloom period. This study provides evidence of an active heterotrophic microbial food web in first-year sea ice, prior to and during the sea-ice algal bloom. This study also highlights the significance of DOC and EPS as integral components of the microbial food web within the sea ice and surface waters of Arctic shelves.
\end{abstract}

KEY WORDS: Bacteria $\cdot$ FLB $\cdot$ Grazing $\cdot$ DOC $\cdot$ EPS $\cdot$ Sea ice $\cdot$ Arctic

\section{INTRODUCTION}

Heterotrophic bacteria and protists are significant components of marine carbon cycling as they regulate the transfer of dissolved organic carbon (DOC) to higher trophic levels (Azam et al. 1983). In addition, bacteria and protists play a key role in the uptake and regeneration of inorganic nutrients, specifically nitrogen, in marine environments (Sherr \& Sherr 2002). Microbial communities are also active in Arctic sea ice
(Laurion et al. 1995, Kaartokallio 2004), as the sea ice contains high concentrations and diverse assemblages of heterotrophic and autotrophic protists and bacteria, in addition to abundant diatom assemblages (Horner \& Schrader 1982, Maranger et al. 1994, Ikävalko \& Gradinger 1997, Sime-Ngando et al. 1997).

Diatoms are generally the major component of firstyear Arctic sea-ice assemblages with bacterial carbon biomass being $\sim 3 \%$ of algal carbon biomass, and bacterial secondary production being $<10 \%$ of ice-algal 
production in landfast sea ice during the spring/summer period (Smith et al. 1989, Smith \& Clement 1990). In Arctic pack ice or in landfast sea ice during winter, bacteria can be important contributors to total sea-ice carbon biomass, potentially surpassing algal or heterotrophic protist (HP) carbon biomass (Gradinger \& Zhang 1997, Gradinger et al. 1999a, Kaartokallio 2004). In addition, bacterial secondary production can surpass primary production when sea-ice algae are light limited in thick pack ice (Grossmann \& Dieckmann 1994).

Bacteria in landfast Arctic sea ice can be much larger than those found in the surface water (Bunch \& Harland 1990, Laurion et al. 1995). In addition, sea-ice bacteria in Arctic pack ice appear to be more active than pelagic bacteria (Junge et al. 2002) and are able to remain metabolically active even at very low temperatures (e.g. $-20^{\circ} \mathrm{C}$ ) and at extreme salinities which can occur within the sea-ice brine channels (e.g. >200 ppt, Junge et al. 2004). Large bacteria and high bacterial activity within the sea ice may be a result of high concentrations of DOC within the sea ice compared to surface waters (Bunch \& Harland 1990, Thomas et al. 1995, Smith et al. 1997), or high concentrations of inorganic and organic particles within the sea ice, since particleassociated bacteria have been found to be more active than free-living bacteria (Sherr et al. 1999).

Few studies have assessed the fate of sea-ice bacteria and the seasonal dynamics of sea-ice heterotrophic protists in the Arctic (e.g. Laurion et al. 1995, SimeNgando et al. 1997). Grazing by heterotrophic protists, especially by small species (e.g. $<5 \mu \mathrm{m}$ flagellates), is known to be an important factor contributing to bacterial mortality and nutrient regeneration in marine systems (for review see Strom 2000, Sherr \& Sherr 2002). In the central Arctic Ocean, heterotrophic protists have been found to be important grazers of phytoplankton and bacteria, and heterotrophic protists $<10 \mu \mathrm{m}$ in size have been found to be the greatest consumers of bacteria (Sherr et al. 1997). Bacterivory in Arctic sea ice has been assessed in only 2 studies, in Resolute Passage (high Canadian Arctic) and Saroma-ko lagoon (Okhotsk Sea), showing heterotrophic microprotists to be an active component of microbial food webs within Arctic sea ice and surface waters (Laurion et al. 1995, Sime-Ngando et al. 1999). To better understand organic carbon cycling in the Arctic Ocean, further research on the microbial transformation of organic carbon within the sea ice is needed, especially over the continental shelves, where sea-ice production is coupled with both pelagic and benthic production (e.g. Michel et al. 1996, Renaud et al. 2007).

This study investigated the grazing of large-sized bacteria by heterotrophic protists within first-year sea ice on the Mackenzie Shelf, Canadian Arctic, during the winter to spring transition. The objectives of this study were to assess the seasonal dynamics of bacteria and protists within the sea ice and surface waters and to determine if bacterivory was sufficient to meet the carbon requirements of sea-ice heterotrophic protists during the sea-ice algal pre-bloom and bloom periods.

\section{MATERIALS AND METHODS}

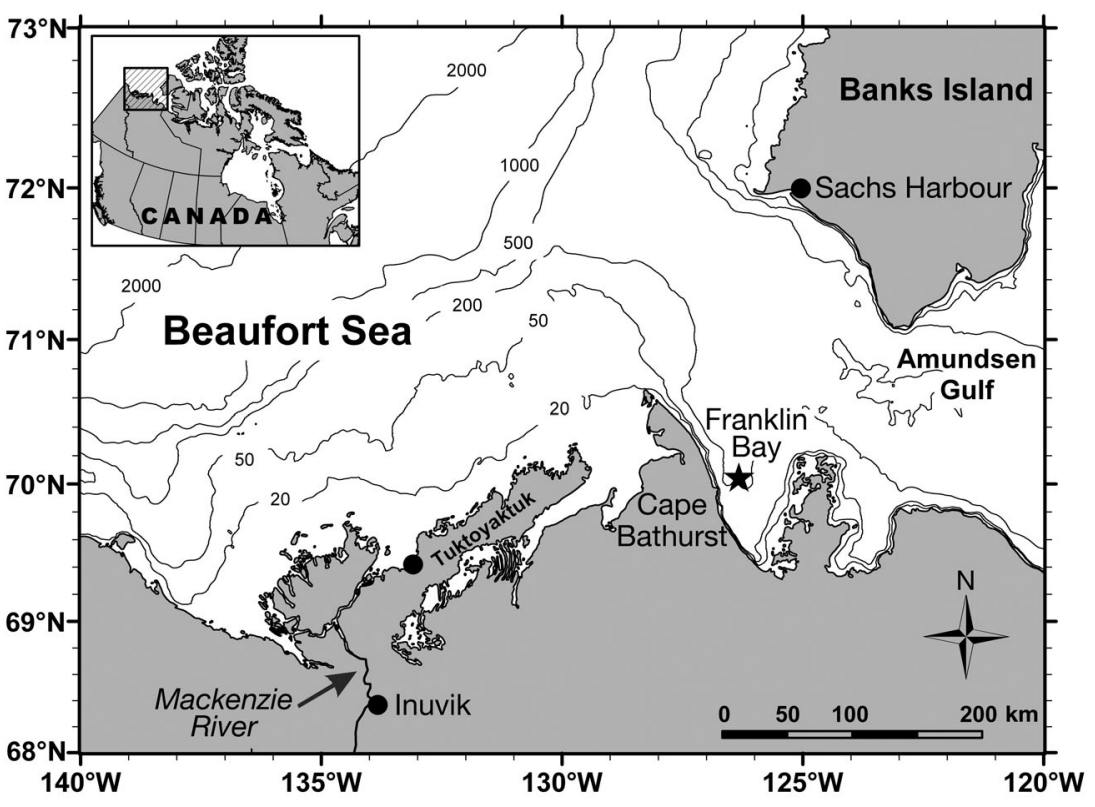

Fig. 1. Sampling station in Franklin Bay (Mackenzie Shelf), Canadian Arctic, as indicated by $\star$. Depth contours in metres
Sampling and analyses. Sea-ice and surface water sampling was conducted in an area of first-year, landfast sea ice in Franklin Bay, Northwest Territories (Fig. 1), every 3 to 5 d between 5 March and 3 May 2004. All samples were collected $1.5 \mathrm{~km}$ northeast of the overwintering site of the CCGS 'Amundsen' $\left(70^{\circ} 04^{\prime} \mathrm{N}\right.$, $126^{\circ} 26^{\prime} \mathrm{W}$; water depth: $250 \mathrm{~m}$ ) as part of the Canadian Arctic Shelf Exchange Study (CASES). Sample analyses and grazing experiments were conducted in laboratories on board the ship shortly after sample collection.

Ice cores were collected with a manual ice corer (Mark II coring system, $9 \mathrm{~cm}$ internal diameter, Kovacs Enterprises) within an area approximately $0.01 \mathrm{~km}^{2}$, with consecutive ice coring conducted within $\sim 10 \mathrm{~m}$ of previous coring sites. On each sampling day, ice cores were collected at 2 sites representative of high and 
low snow cover to account for some of the horizontal patchiness in sea-ice biomass (Gosselin et al. 1986, Rysgaard et al. 2001).

At the high and low snow cover sampling sites, multiple cores were collected for routine analysis of DOC, exopolymeric substances (EPS), chlorophyll a (chl a), protist and bacterial abundances, and for fluorescently labeled bacteria (FLB) grazing experiments. The bottom $4 \mathrm{~cm}$ of 3 to 5 ice cores was pooled together in an isothermal container, to obtain one sample for each snow cover depth. Sterile gloves were worn at all times during the manipulation of the cores. On each sampling day, water from the ice-water interface was also collected using a hand pump. One subsample of this surface water was analyzed for DOC, EPS, chl $a$, and cells counts. A second subsample was filtered through $0.2 \mu \mathrm{m}$ polycarbonate membrane filters and added to the ice core samples to minimize osmotic stress during the melting process (Garrison \& Buck 1986). A separate ice core, kept in a sterile Whirl-Pak bag, was melted without the addition of filtered surface water for the analysis of sea-ice DOC. Sea-ice concentrations of measured variables and experimental results were corrected for the dilution from the addition of seawater during the melting process, when applicable.

Chl $\boldsymbol{a}$, EPS and DOC. Chl a was determined fluorometrically (10AU Turner Designs) on duplicate subsamples filtered on Whatman GF/F filters, after $24 \mathrm{~h}$ extraction in $90 \%$ acetone at $5^{\circ} \mathrm{C}$ in the dark (Parsons et al. 1984). Triplicate EPS subsamples were filtered on $47 \mathrm{~mm} 0.4 \mu \mathrm{m}$ Nuclepore filters and stained with Alcian blue. EPS, operationally defined as $>0.4 \mu \mathrm{m}$ acidic exopolysaccharides, were measured colorimetrically (787 nm) after a $2 \mathrm{~h}$ extraction in $80 \% \mathrm{H}_{2} \mathrm{SO}_{4}$ (Passow \& Alldredge 1995). EPS concentrations were recorded as $\mu$ g gum xanthan equivalents (xeq.) $\mathrm{l}^{-1}$ and converted to carbon equivalents $\left(\mu \mathrm{g} \mathrm{l}^{-1}\right.$ ) according to Engel (2004). Duplicate DOC subsamples were filtered through precombusted $\left(450^{\circ} \mathrm{C}\right.$ for $\left.5 \mathrm{~h}\right)$ Whatman $\mathrm{GF} / \mathrm{F}$ filters using acid-washed syringe filters, acidified with $50 \% \mathrm{H}_{3} \mathrm{PO}_{4}$ and stored at $4{ }^{\circ} \mathrm{C}$ until analysis using a Tekmar/Dohrman (Apollo 9000) analyzer.

Bacteria and protists. Subsamples for bacterial $(10 \mathrm{ml})$ and protist $(20 \mathrm{ml})$ counts were preserved with buffered formaldehyde (1\% final concentration), stained with DAPI (4',6-diamidino-2-phenylindole) at a final concentration of $1 \mu \mathrm{g} \mathrm{ml}^{-1}$ and filtered on 0.2 and $0.8 \mu \mathrm{m}$ black Nuclepore filters, respectively (Sherr et al. 1993). A minimum of 200 free-living bacteria was counted in 10 fields from duplicate subsamples using epifluorescent microscopy. Total bacterial abundances represent the sum of small (i.e. $<0.7 \mu \mathrm{m}$ ) spherical and large $(\geq 0.7 \mu \mathrm{m})$ rod-shaped bacteria. When present, diatom-attached bacteria were also counted. In this study, autotrophic bacteria were not observed under blue light excitation, therefore, total bacterial counts represent heterotrophic bacteria only.

Autotrophic and heterotrophic protists, excluding pennate and centric diatoms, were counted at $400 \times$ and $1000 \times$ magnification with, on average, a minimum of 100 cells counted. Cells were separated into 2 size classes, with the abundance of cells $>5 \mu \mathrm{m}$ in diameter determined from the average cell counts at the 2 magnifications and the abundance of cells $\leq 5 \mu \mathrm{m}$ in diameter obtained from cell counts at $1000 \times$ only. Autotrophic protists were identified by chlorophyll autofluorescence under blue light excitation. Autotrophic and heterotrophic protists will hereafter be referred to as autotrophs and heterotrophs. Ciliates, which can be important bacterivores, were not observed in our samples and were thus not included in the protist counts. We acknowledge that our methods would not adequately quantify ciliates.

The size of each protist cell counted was measured using image analysis software (Image Pro 5.1). Biovolumes were estimated based on the nearest geometric shape (Hillebrand et al. 1999) and carbon biomass content was estimated according to the carbon to volume relationship of Menden-Deuer \& Lessard (2000), pg C cell ${ }^{-1}=0.216 \times\left(\mathrm{mm}^{3} \text { cell }^{-1}\right)^{0.939}$. A subsample of 600 bacterial cells was also measured using the same image analysis system and bacterial carbon content was estimated using the carbon-to-volume relationship of Simon \& Azam (1989) as modified by Norland (1993): pg $\mathrm{C} \mathrm{cell}^{-1}=0.12 \times\left(\mathrm{um}^{3} \mathrm{cell}^{-1}\right)^{0.7}$.

FLB grazing experiments. Bacterivory rates from sea ice under high $(\mathrm{n}=11)$ and low $(\mathrm{n}=11)$ snow cover were estimated from the disappearance of FLB. The FLB were added to Whirl-Pak bags containing sea-ice subsamples (1 l experimental volume) which had been melted with the addition of filtered sea water, as described above. The subsamples were gently prescreened $(200 \mu \mathrm{m})$ to exclude protist predators from the experiments. During the sea-ice algal bloom, $425 \mu \mathrm{m}$ mesh size was used to avoid removing large chain and branching diatoms which would otherwise have been retained on the $200 \mu \mathrm{m}$ mesh.

Laboratory control experiments $(n=5)$ were conducted a posteriori to determine the disappearance of FLB from particle and predator-free seawater, under the same conditions as the grazing experiments. During the control experiments, FLB concentrations decreased at a rate of $8.6 \times 10^{6} \mathrm{FLB} \mathrm{I}^{-1} \mathrm{~d}^{-1}$ representing, on average, $9.7 \pm 8.4$ ( $1 \mathrm{SD}$ ) \% of observed community grazing rates. All community grazing rates were corrected for the loss of FLB during the control experiments.

The FLB were stained with dichlorotriazinylamino fluorescein (DTAF) according to Sherr \& Sherr (1993) 
and were added at a final concentration of 3 to $41 \%$ (average $12 \%$ ) of natural sea-ice bacterial abundances. FLB were prepared from cultured bacteria, isolated from first-year sea ice of the Chukchi Sea (Strain 11B5, provided by K. Junge \& J. Deming). The size range of the rod-shaped FLB ranged from 1 to $3.4 \mu \mathrm{m}$ and was comparable to the size range of the large rod-shaped, sea-ice bacteria observed during our study, i.e. 0.7 to $4.2 \mu \mathrm{m}$. Therefore, our grazing estimates are for large-sized bacteria only.

The sea-ice samples were incubated at sub-ice light conditions from under high snow cover $(2.2 \pm 0.32 \mu \mathrm{E}$ $\mathrm{m}^{-2} \mathrm{~s}^{-1}$ ), as measured with a Li-1923B underwater $2 \pi$ PAR (photosynthetically available radiation, 400 to $700 \mathrm{~nm})$ sensor, and at near in situ temperature $\left(0^{\circ} \mathrm{C}\right)$. The subsamples were incubated for 96 or $72 \mathrm{~h}$ prior to 13 April, after which the experimental duration was decreased to $48 \mathrm{~h}$ as the abundance of potential grazers (i.e. heterotrophic protists) increased within the sea ice. Duplicate subsamples for flow cytometry $(1.5 \mathrm{ml})$ and microscopic counts $(10 \mathrm{ml})$ were taken every 2 to $12 \mathrm{~h}$, at which time the bags were gently mixed. Chl a concentrations at the beginning and end of each FLB grazing experiment were also assessed. Total chl a concentrations were determined as described above and size-fractionated chl a concentrations (>5 $\mu \mathrm{m})$ were determined using $5 \mu \mathrm{m}$ Poretics polycarbonate membrane filters.

Naturally occurring bacteria were counted microscopically at the beginning and end of each FLB grazing experiment as described above. FLB subsamples were preserved with paraformaldehyde (1\% final concentration), stored at $-80^{\circ} \mathrm{C}$ and later analyzed using an Epics Altra flow cytometer (Beckman-Coulter) fitted with a $15 \mathrm{~mW}, 488 \mathrm{~nm}$ laser. DTAF fluorescence was measured at $525 \pm 5 \mathrm{~nm}$ and FLB were identified from their typical signature in plots of side scatter (SSC) versus green fluorescence. For each FLB subsample, 10000 events were acquired, and the weight of the subsample before and after each analysis was measured to calculate the number of FLB $\mathrm{ml}^{-1}$. Flow cytometry and microscopic counts $(n=10)$ were compared using Model I regression (Sokal \& Rohlf 1995). There was a significant linear relationship between flow cytometric counts $(y)$ and microscopic counts $(x)(y=$ $\left.1.3 x-0.09, \mathrm{r}^{2}=0.55, \mathrm{p}<0.05\right)$.

Model I linear regressions were used to determine if the observed rates of decrease in FLB concentrations during the grazing experiments were significantly different than zero (Sokal \& Rohlf 1995). Community grazing rates $\left(G\right.$, bacteria $\left.\mathrm{l}^{-1} \mathrm{~d}^{-1}\right)$ were calculated using the initial and final ratios of FLB and naturally occurring large-sized bacteria in the experimental subsamples, according to Model 3 of Salat \& Marrasé (1994). Community grazing rates were then divided by the average abundance of sea-ice heterotrophs on each sampling date to calculate heterotrophic protist ingestion rates (bacteria $\mathrm{HP}^{-1} \mathrm{~d}^{-1}$ ). The underlying assumption is that grazing by heterotrophs was the only factor responsible for the disappearance of FLB, after correcting for the disappearance of FLB from the control experiments. We calculated instantaneous net bacterial growth rates $\left(a, \mathrm{~d}^{-1}\right)$ according to Model 3 of Salat \& Marrasé (1994). These growth rates were multiplied by average large-sized bacterial biomass ( $\mu \mathrm{C} \mathrm{C}^{-1}$ ) to estimate large-sized bacterial production

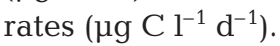

In conjunction with each grazing experiment, $250 \mathrm{ml}$ sea-ice subsamples were incubated in the dark at $0^{\circ} \mathrm{C}$ to assess net changes in $\mathrm{NH}_{4}$ concentrations over a $24 \mathrm{~h}$ period. $\mathrm{NH}_{4}$ concentrations in these dark incubations were analyzed every $6 \mathrm{~h}$ using the salicylatehypochlorite method (Bower \& Holm-Hansen 1980). Net ammonium regeneration rates were determined from the slope of the change in $\mathrm{NH}_{4}$ concentrations over the $24 \mathrm{~h}$ period (Model I linear regression, Sokal \& Rohlf 1995).

Calculations and statistical analyses. Carbon requirements (pg C $\mathrm{HP}^{-1} \mathrm{~d}^{-1}$, Laurion et al. 1995) of the heterotrophic protists during the pre-bloom (5 March to 3 April) and sea-ice algal bloom (8 April to 3 May) periods of this study were estimated as follows:

$$
\text { Carbon requirement }=f \times r / \mathrm{GE}
$$

where $f$ is the carbon content of the heterotrophic protist (pg C $\left.\mathrm{HP}^{-1}\right), r$ is the specific growth rate $\left(\mathrm{d}^{-1}\right)$ and GE is the growth efficiency $(0.33$, Hansen et al. 1997). $r$ was estimated according to $\left(\ln N_{t}-\ln N_{0}\right) / t$, where $N_{t}$ and $N_{0}$ are the final and initial heterotrophic protist biomass ( $\mathrm{HP}, \mu \mathrm{g} \mathrm{C \textrm {Cl } ^ { - 1 }}$ ), respectively, after $t$ days (i.e. 30 and $26 \mathrm{~d}$ for the pre-bloom and bloom periods, respectively).

Kendall's coefficients of rank correlation $(\tau)$ and partial correlation coefficients $(p \tau)$ were used to infer the strength of associations between 2 variables (Sokal \& Rohlf 1995). Wilcoxon's signed-ranks tests were used to compare paired variates from the high and low snow cover sites and from the FLB grazing experiments. Statistical analyses were carried out using JMP (SAS Institute).

\section{RESULTS}

Sea-ice thickness increased from $1.5 \mathrm{~m}$ to a maximum of $1.9 \mathrm{~m}$ under high snow cover and from $1.6 \mathrm{~m}$ to a maximum of $1.9 \mathrm{~m}$ under low snow cover from 5 March to 3 May in Franklin Bay. Seasonally averaged snow depth at the high and low snow cover sites was $14.8 \pm 3.0(1 \mathrm{SD})$ and $3.6 \pm 1.6 \mathrm{~cm}$, respectively. 


\section{Chl $a$, EPS and DOC}

Chl a concentrations averaged $23.8 \mu \mathrm{g} \mathrm{l}^{-1}$ (range 0.3 to $74.7 \mu \mathrm{g} \mathrm{l}^{-1}$ ) and $137.5 \mu \mathrm{g} \mathrm{l}^{-1}$ (range 3.1 to $496.4 \mu \mathrm{g} \mathrm{l}^{-1}$ ) in the bottom of the sea ice under high and low snow cover. In the surface water, chl a concentrations averaged $0.28 \mu \mathrm{g} \mathrm{l}^{-1}$ and ranged from 0.10 to $0.64 \mu \mathrm{g} \mathrm{l}^{-1}$. Chl a concentrations were significantly higher in sea ice under low snow cover than high snow cover (Wilcoxon's, $\mathrm{p}<0.01$ ). Sea-ice EPS-carbon concentrations varied between 57 and $492{\mu \mathrm{gl}^{-1}}^{-1}$ and between 64 and $4714 \mu^{-1} \mathrm{l}^{-1}$ in the sea ice under high and low snow cover, respectively, whereas surface water EPScarbon concentrations ranged from below detection to $37 \mu \mathrm{g} \mathrm{l}^{-1}$. EPS-carbon concentrations were significantly higher in sea ice under low snow cover than high snow cover (Wilcoxon's, p < 0.05). The onset of the sea-ice algal bloom in this study is indicated by a rapid increase in chl a concentrations beginning ca. 3 April. A detailed description of seasonal chl $a$ and EPS concentrations is presented in Riedel et al. (2006).
Sea-ice DOC concentrations averaged 88 and $239 \mu \mathrm{M}$ under high and low snow cover, respectively, with concentrations rapidly increasing after 3 April (Fig. 2A), corresponding with the onset of the sea-ice algal bloom. Surface water DOC concentrations averaged $133 \mu \mathrm{M}$ and varied between 100 and $267 \mu \mathrm{M}$ (Fig. 2B). DOC concentrations in the sea ice under low snow cover and in surface waters were both significantly higher than DOC concentrations in the sea ice under high snow cover (Wilcoxon's, $\mathrm{p}<0.05$ ). There was no significant difference between DOC concentrations in sea ice under low snow cover and in surface waters (Wilcoxon's, $\mathrm{p}=0.90$ ).

Significant correlations were observed between seaice DOC and chl a concentrations (high and low snow: $\tau=0.73, \mathrm{p}<0.01$ ) (Fig. 2C) and between sea-ice DOC and EPS-carbon concentrations (high snow: $\tau=0.71$, $p<0.01$, low snow: $\tau=0.94, p<0.001$ ) (Fig. 2D). In surface waters, DOC concentrations were not significantly correlated to either chl a $(\mathrm{p}=0.15)$ or EPS-carbon $(p=0.53)$ concentrations.
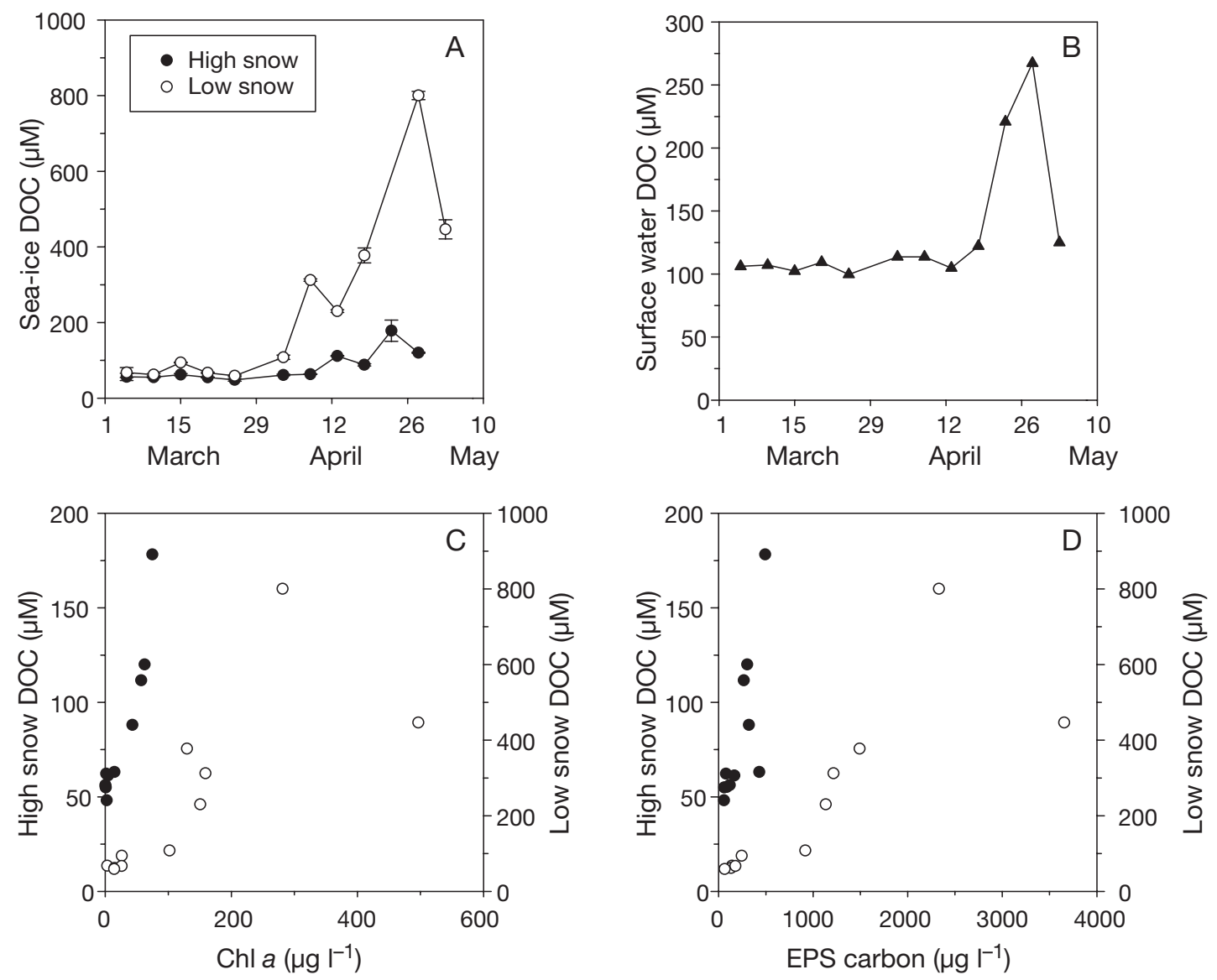

Fig. 2. $(A, B)$ Seasonal trends in the concentrations of (A) sea-ice dissolved organic carbon (DOC) and (B) surface water DOC in 2004. (C,D) Relationship between (C) DOC and chlorophyll a (chl a) concentration and (D) DOC and exopolymeric substances-carbon (EPS-carbon) concentration in the sea ice under high and low snow cover. In (A), means \pm SD are shown 
Table 1. Abundance of bacteria, and autotrophic and heterotrophic protists in the sea ice under high and low snow cover, and in surface waters on the Mackenzie Shelf, March to May 2004 ( $\mathrm{n}=11$ ). Total bacteria represent free-living cells only

\begin{tabular}{|c|c|c|c|c|c|c|}
\hline & \multicolumn{2}{|c|}{$\begin{array}{c}\text { Bacteria } \\
\left(10^{9} \text { cells } 1^{-1}\right)\end{array}$} & \multicolumn{2}{|c|}{$\begin{array}{l}\text { Autotrophs } \\
\left(10^{6}{\left.\text { cells } 1^{-1}\right)}^{-1}\right.\end{array}$} & \multicolumn{2}{|c|}{$\begin{array}{c}\text { Heterotrophs } \\
\left(10^{6} \text { cells } l^{-1}\right)\end{array}$} \\
\hline & Total & Large & $\leq 5 \mu \mathrm{m}$ & $>5 \mu \mathrm{m}$ & $\leq 5 \mu \mathrm{m}$ & $>5 \mu \mathrm{m}$ \\
\hline \multicolumn{7}{|l|}{ Sea ice } \\
\hline \multicolumn{7}{|l|}{ High snow } \\
\hline Average & 1.3 & 0.43 & 0.55 & 0.73 & 0.19 & 0.20 \\
\hline Range & $0.44-2.6$ & $0.03-1.8$ & $0-2.1$ & $0.01-3.1$ & $0-0.6$ & $0.02-0.62$ \\
\hline \multicolumn{7}{|l|}{ Low snow } \\
\hline Average & 1.5 & 0.59 & 0.28 & 0.54 & 0.15 & 0.38 \\
\hline Range & $0.30-2.7$ & $0.02-1.5$ & $0.01-1.1$ & $0.05-1.2$ & $0.004-0.63$ & $0.02-1.3$ \\
\hline \multicolumn{7}{|c|}{ Surface waters } \\
\hline Average & 0.63 & 0.26 & 0.10 & 0.01 & 0.05 & 0.01 \\
\hline Range & $0.19-0.89$ & $0.02-0.53$ & $0-0.26$ & $0.002-0.04$ & $0.001-0.12$ & $0.002-0.03$ \\
\hline
\end{tabular}

\section{Bacteria and protists}

Average and range abundances of autotrophic and heterotrophic protists in the sea ice and surface waters are summarized in Table 1. In sea ice, under high and low snow cover, $>5 \mu \mathrm{m}$ autotrophs were, on average, the most abundant protists, whereas $\leq 5 \mu \mathrm{m}$ autotrophs were, on average, most abundant in surface waters.

Sea-ice protist abundances gradually increased, starting in April, and the abundance of all $>5 \mu \mathrm{m}$ protists (autoand heterotrophs) remained high for the rest of the sampling period (Fig. 3A,C). In April, the abundance of all $>5 \mu \mathrm{m}$ protists (auto- and heterotrophs) and $\leq 5 \mu \mathrm{m}$ autotrophs rapidly increased in surface waters (Fig. 3A-C). The abundance of $\leq 5 \mu \mathrm{m}$ heterotrophs did not show any clear seasonal trend in the sea ice or surface waters (Fig. 3D). In the sea ice, the abundance of protists was not significantly different between high and low snow cover sites (calculated for each $\leq 5$ and $>5 \mu \mathrm{m}$ autotrophic and heterotrophic group separately: Wilcoxon's, $\mathrm{p}=0.44$ to 0.72 ).

Total, free-living bacterial abundances in the sea ice and surface water are summarized in Table 1 and Fig. 4A. Total sea-ice bacterial abundances were not significantly different between high and low snow
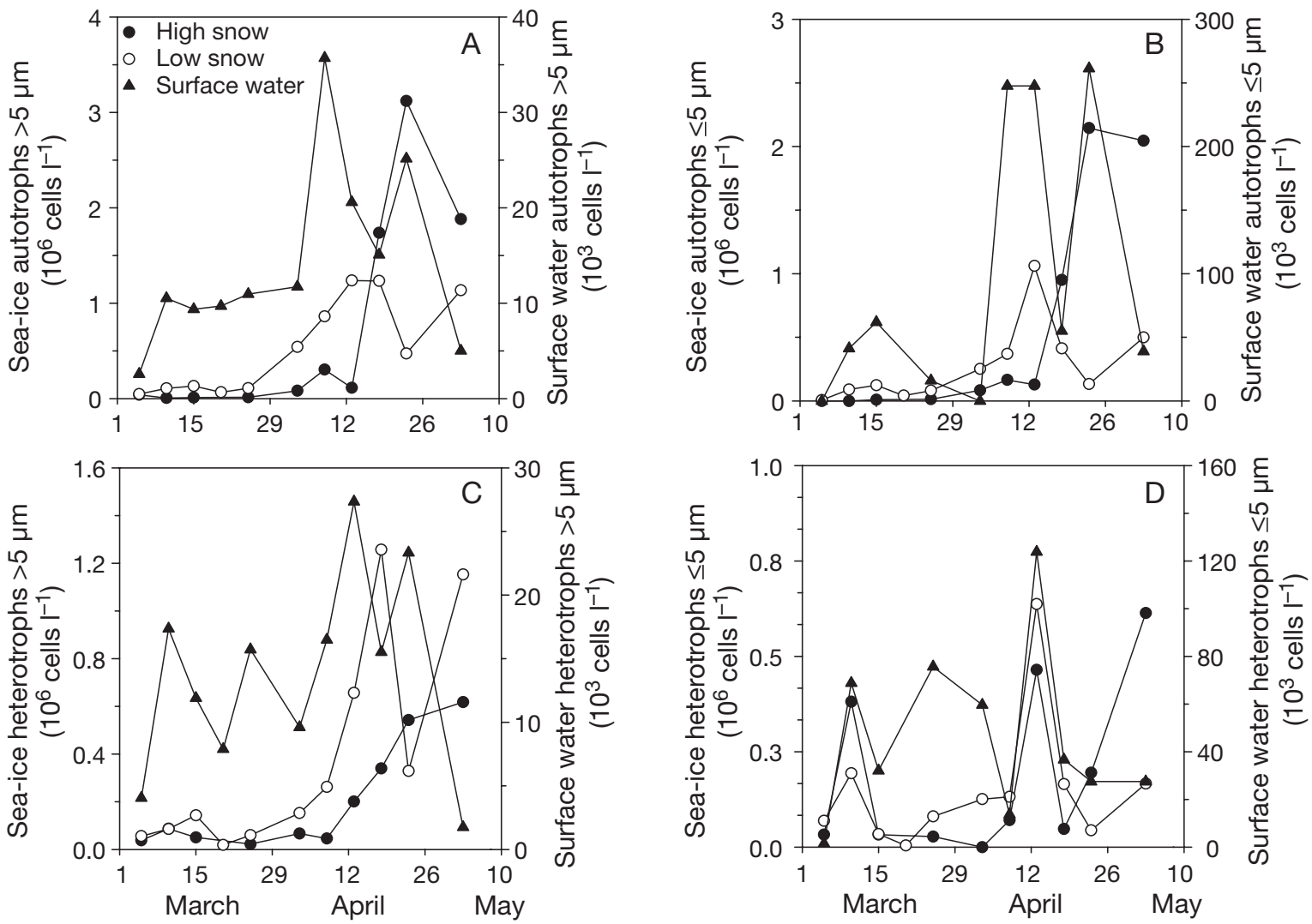

Fig. 3. Seasonal trends in high and low snow cover sea ice and surface water abundances of (A) $>5 \mu \mathrm{m}$ autotrophs, (B) $\leq 5 \mu \mathrm{m}$ autotrophs, (C) $>5 \mu \mathrm{m}$ heterotrophs and (D) $\leq 5 \mu \mathrm{m}$ heterotrophs in 2004 

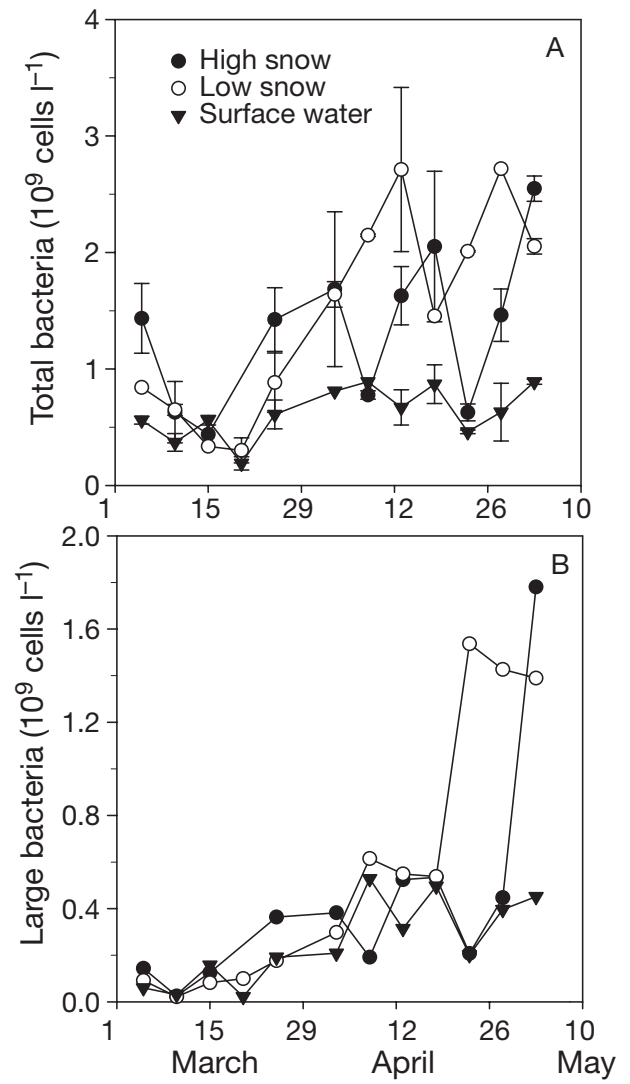

Fig. 4. Seasonal trends in (A) total bacterial and (B) large $(\geq 0.7 \mu \mathrm{m})$ bacterial abundances in the sea ice under high and low snow cover, and in surface waters in 2004. In (A), means $\pm \mathrm{SD}$ are shown

cover (Wilcoxon's, $\mathrm{p}=0.56$ ). However, total sea-ice bacterial abundances under high (Wilcoxon's, p < 0.05) and low (Wilcoxon's, p < 0.05) snow cover were significantly higher than bacterial abundances in surface waters. Total sea-ice bacterial abundances were, on average, 1 order of magnitude higher than in the surface water.

Total bacterial abundances were significantly correlated with DOC $(\tau=0.48, p<0.05)$ concentrations under low snow cover only. However, partial correlation analyses found that this correlation was not substantiated due to intercorrelations with EPS-carbon and chl a concentrations. The correlation between total bacterial abundances and DOC concentrations under low snow cover decreased from $\tau=0.48$ to $\mathrm{p} \tau=0.30$ and $\mathrm{p} \tau=0.21$ when the effects of EPS-carbon and chl $a$ were controlled, respectively.

The cellular carbon content of small- and large-sized, sea-ice bacteria was 0.019 and $0.093 \mathrm{pg} \mathrm{C}$ cell $^{-1}$, respectively. The abundance of large-sized bacteria averaged $0.43,0.57$ and $0.26 \times 10^{9}$ cells $1^{-1}$ under high and low snow and in surface waters, respectively (Table 1, Fig. 4B). The large-sized, sea-ice bacteria contributed, on average, $28 \%$ (range 4 to $70 \%$ ) and $33 \%$ (range 3 to $76 \%$ ) of total bacterial abundances under high and low snow cover, respectively. In surface waters, large-sized bacteria contributed an average of $36 \%$ (range 8 to $63 \%$ ) of total bacterial abundances. The abundance of largesized bacteria and their contribution to total bacterial abundances in the sea ice were not significantly different between high and low snow cover (Wilcoxon's, $p=0.76$ to 0.85$)$. There was also no significant difference in the abundance of large-sized bacteria and their percent contribution to total bacterial abundances between the sea ice and surface waters (Wilcoxon's, high snow: $\mathrm{p}=0.27$ to 0.44 ; low snow: $\mathrm{p}=0.24$ to 0.64 ).

Fig. 5 shows log-log correlations between largesized bacterial and protist abundances in the sea ice. Bacterial abundances were significantly correlated with the abundance of $>5 \mu \mathrm{m}$ autotrophs under high $(\tau=0.51, p<0.05)$ and low snow cover $(\tau=0.55, \mathrm{p}<$ 0.05) (Fig. 5A), and with the abundance of $\leq 5 \mu \mathrm{m}$ autotrophs under high $(\tau=0.49, \mathrm{p}<0.05)$ and low snow cover $(\tau=0.55, \mathrm{p}<0.05)$ (Fig. 5B).

Large-sized sea-ice bacterial abundances were not correlated with the abundance of heterotrophs ( $p=0.17$ to 0.79$)$, except $>5 \mu \mathrm{m}$ heterotrophs $(\tau=0.55$, $\mathrm{p}<0.05$ ) under low snow cover (Fig. 5C,D). In surface waters, bacterial abundances were not correlated with the abundance of any protist group ( $\mathrm{p}=0.06$ to 0.72 , results not shown).

From 8 April onward, diatom-attached bacteria were observed in the sea ice only. These bacteria were consistently large rods, which varied in abundance between 0.6 and $305 \times 10^{6}$ cells $\mathrm{l}^{-1}$. Highest concentrations occurred in the sea ice under low snow cover (data not shown).

\section{Grazing experiments}

The rate of change in net sea-ice $\mathrm{NH}_{4}$ concentrations over a $24 \mathrm{~h}$ period (i.e. the slope of the regression) was significantly different from zero $(\mathrm{p}<0.05)$ in only 2 high snow and 4 low snow cover experiments. In the 2 high snow cover experiments, both regeneration $(1.5 \mu \mathrm{M}$ $\left.\mathrm{d}^{-1}\right)$ and consumption $\left(0.70 \mu \mathrm{M} \mathrm{d}^{-1}\right)$ were observed. In the 4 low snow cover experiments there was an average net $\mathrm{NH}_{4}$ consumption rate of $1.68 \pm 0.72(1 \mathrm{SD}) \mu \mathrm{M} \mathrm{d}^{-1}$.

During the grazing experiments, total and $>5 \mu \mathrm{m}$ chl a concentrations in the sea ice generally decreased. However, total and $>5 \mu \mathrm{m}$ chl a concentrations were not significantly different between the beginning and end of any sea-ice FLB grazing experiment (Wilcoxon's, $p=0.25$ to 0.73 ). Large-sized bacterial abundances significantly increased during the grazing experiments (high snow: average rate $0.30 \mathrm{~d}^{-1}$, Wilcoxon's $\mathrm{p}<0.01$; low snow: average rate $0.46 \mathrm{~d}^{-1}$, Wilcoxon's $\mathrm{p}<0.01$ ), whereas the abundance of small 

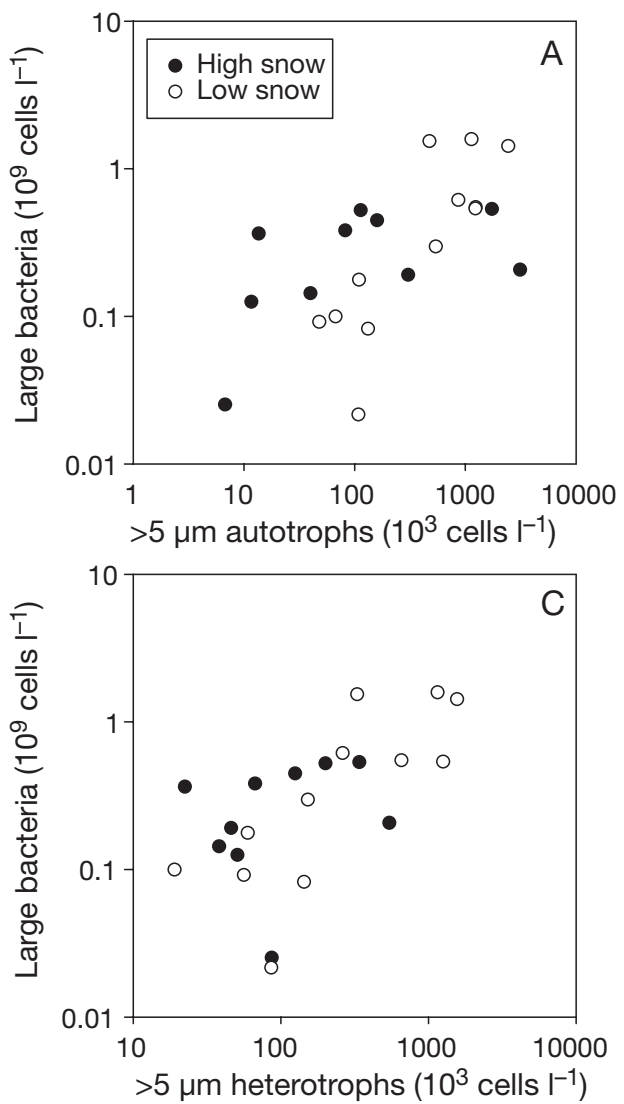

Fig. 5. Relationship between the abundance of large-sized bacteria and that of (A) $>5 \mu \mathrm{m}$ autotrophs, (B) $\leq 5 \mu \mathrm{m}$ autotrophs, (C) $>5 \mu \mathrm{m}$ heterotrophs and (D) $\leq 5 \mu \mathrm{m}$ heterotrophs, in the sea ice under high and low snow cover. Note log scales bacteria $\mathrm{l}^{-1} \mathrm{~d}^{-1}$ in the sea ice under high and low snow, respectively (Fig. 6A). On average, $55 \pm 63$ (1 SD) and $59 \pm 52 \%$ of the large-sized, freeliving, bacteria, in the sea ice under high and low snow cover, respectively, could be grazed each day according to the observed community grazing rates. Community grazing rates were not significantly different between high and low snow cover sites (Wilcoxon's, p = 0.62, Fig. 6A).

Ingestion rates were higher prior to than following the onset of the sea-ice algal bloom (i.e. 3 April, Fig. 6B). The large-sized bacteria were ingested at rates varying between 14 and 3384 bacteria $\mathrm{HP}^{-1} \mathrm{~d}^{-1}$ and 52 and 2235 bacteria $\mathrm{HP}^{-1} \mathrm{~d}^{-1}$, in the sea ice under high and low snow cover, respectively (Fig. 6B). Sea-ice heterotrophic ingestion rates were not significantly different between high and low snow cover (Wilcoxon's, p =0.94, Fig. 6B).

Growth rates and carbon requirements of sea-ice heterotrophs, under high and low snow cover, are summarized in Table 2 for the sea-ice algal pre-bloom and bloom periods. The consumption of large-sized bacteria bacteria did not change significantly during any of the grazing experiments (Wilcoxon's, $p=0.31$ to 0.65 ). The production rate of large-sized bacteria during the grazing experiments was estimated to be 0.9 and $1.0 \mu \mathrm{g} \mathrm{C}$ $\mathrm{l}^{-1} \mathrm{~h}^{-1}$, from high and low snow sites, respectively.

The linear decrease in FLB concentrations over the entire incubation period (i.e. the slope of the regression) was significantly different from zero $(p<0.05)$ for all grazing experiments, except under high snow cover on 28 April. In this one experiment, a linear decrease was observed during the first $10 \mathrm{~h}$ of the experiment, with no further decrease for the remainder of the $48 \mathrm{~h}$ experiment. The results of this experiment were excluded from our dataset.

The rates at which the large-sized bacteria were grazed varied seasonally with no clear seasonal trends (Fig. 6A). Community grazing rates varied between 0.95 and $219 \times 10^{6}$ bacteria $\mathrm{l}^{-1} \mathrm{~d}^{-1}$ and 19 and $859 \times 10^{6}$

Fig. 6. March to May 2004 seasonal trends in (A) community grazing and (B) ingestion rates of large-sized bacteria by heterotrophic protists (HP) in the sea ice under high and low snow cover
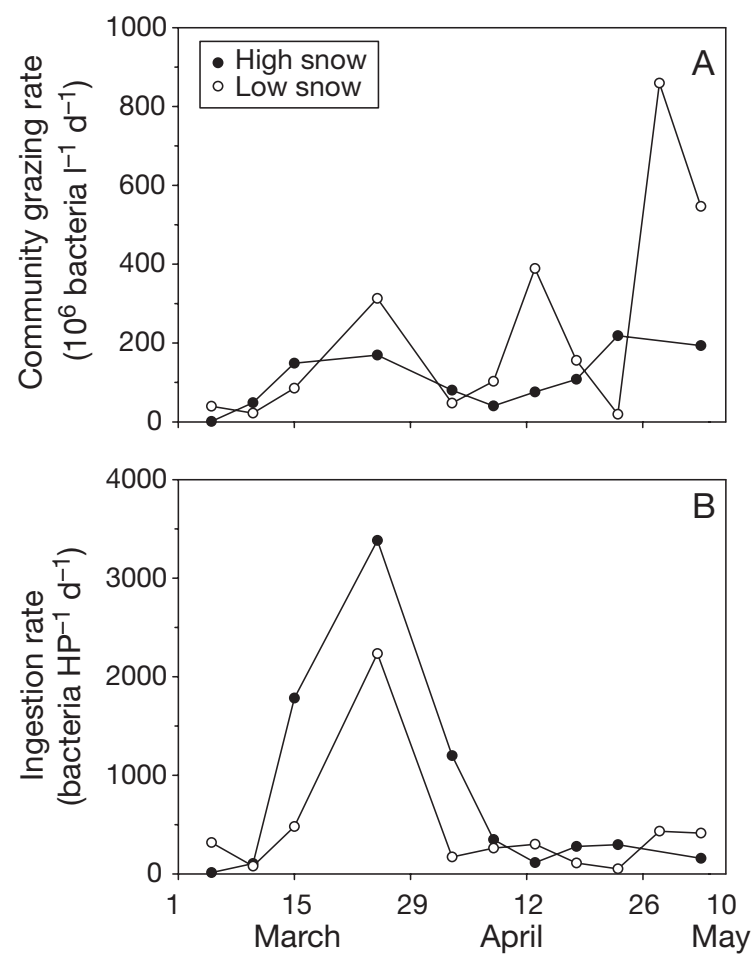
satisfied sea-ice heterotrophic carbon requirements during the sea-ice algal pre-bloom period only. Ingestion rates of sea-ice heterotrophs were negatively correlated with DOC and EPS-carbon concentrations under high (DOC: $\tau=-0.64, p<0.05$; EPS-carbon: $\tau=$ $-0.57, \mathrm{p}<0.05$ ) and low (DOC: $\tau=-0.56, \mathrm{p}<0.05$; EPScarbon: $\tau=-0.56, p<0.05$ ) snow cover (Fig. 7A,B).

\section{DISCUSSION}

Arctic sea ice appears to be a more favorable growth environment for heterotrophic bacteria, than the pelagic zone, as indicated by high sea-ice bacterial abundances and large cell sizes. Bacterial abundances in the sea ice on the Mackenzie Shelf were within the range previously observed for Antarctic (Gowing et al. 2004 and references therein) and Arctic sea ice (Bunch \& Harland 1990, Gradinger \& Zhang 1997). Bacterial abundances from the ice-water interface were also comparable with previous estimates for surface waters in the same area (Garneau et al. 2006).

High abundances of large-sized bacteria in the sea ice during this study (Fig. 4B) also agree with previous studies of landfast sea ice in the Arctic (Bunch \& Harland 1990, Laurion et al. 1995, Kaartokallio 2004). The study by Laurion et al. (1995) did not report the presence of large-sized bacteria in surface waters collected only $5 \mathrm{~cm}$ from the bottom of the sea ice. However, in our study, the abundance of large-sized bacteria in surface waters near the ice-water interface was not significantly different than large-sized, sea-ice bacterial abundances. This suggests that on the Mac-

Table 2. Sea-ice heterotrophic protist growth rates $\left(\mathrm{d}^{-1}\right)$ and carbon requirements (pg Cell ${ }^{-1} \mathrm{~d}^{-1}$ ) during the sea-ice algal pre-bloom (5 March to 3 April) and bloom (8 April to 3 May) periods of this study. Ingestion rates (bacteria $\mathrm{HP}^{-1} \mathrm{~d}^{-1}$ ) required to satisfy estimated carbon requirements and observed ingestion rates from the grazing experiments are based on the consumption of large-sized, sea-ice bacteria. Details of calculations in 'Materials and methods'

\begin{tabular}{|c|c|c|c|c|}
\hline & \multicolumn{2}{|c|}{ Heterotrophic } & \multicolumn{2}{|c|}{ Ingestion rate } \\
\hline & $\begin{array}{l}\text { Growth } \\
\text { rate }\end{array}$ & $\begin{array}{l}\text { Carbon } \\
\text { required }\end{array}$ & Required & Observed \\
\hline \multicolumn{5}{|l|}{ High snow } \\
\hline Pre-bloom & 0.08 & 55 & 604 & $1297^{a}$ \\
\hline Bloom & 0.09 & 93 & 1013 & 239 \\
\hline \multicolumn{5}{|l|}{ Low snow } \\
\hline Pre-bloom & 0.05 & 38 & 410 & $657^{a}$ \\
\hline Bloom & 0.07 & 69 & 748 & 262 \\
\hline
\end{tabular}
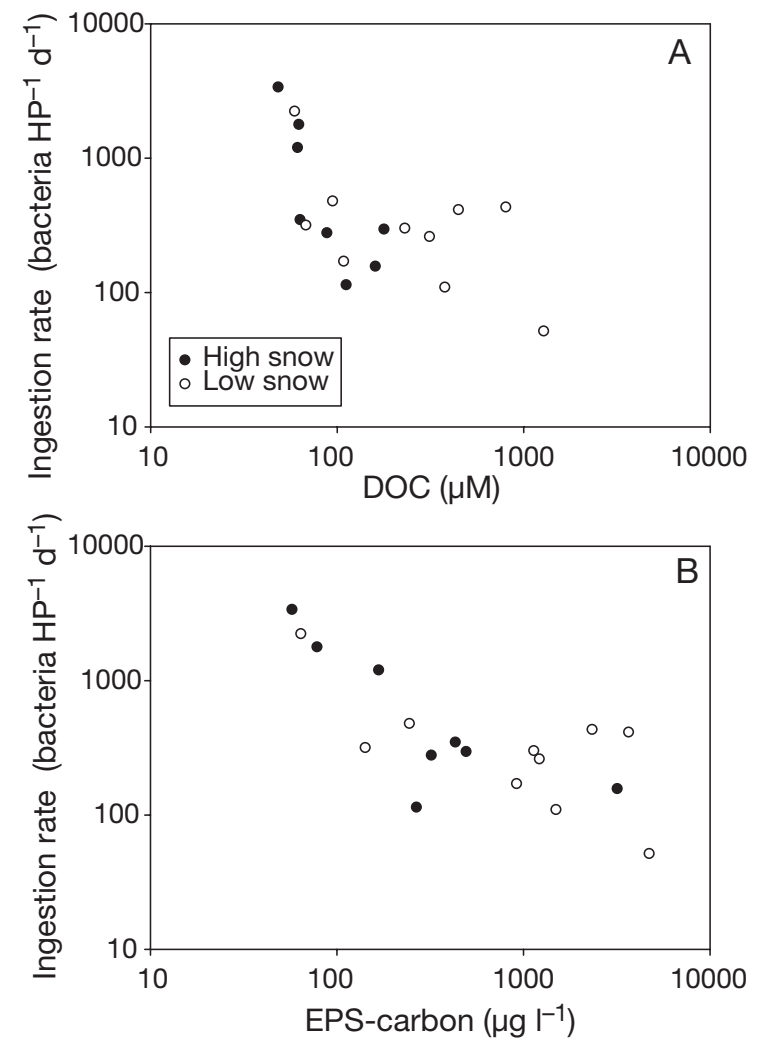

Fig. 7. Relationship between heterotrophic protist (HP) ingestion rates and (A) dissolved organic carbon (DOC), and (B) exopolymeric substances-carbon (EPS-carbon) concentrations, in the sea ice under high and low snow cover. Note log scales

kenzie Shelf there may be an exchange of large-sized bacteria between the sea ice and interfacial waters, or that the interfacial water also constitutes a favorable growth environment for bacteria, possibly in relation to high DOC concentrations (Fig. 2B).

The distribution of sea-ice biomass is notoriously patchy due to small scale variation in snow cover thickness, which influences light availability at the bottom of the sea ice (Gosselin et al. 1986, Mundy et al. 2005). This variability in bottom ice irradiance results in heterogeneous distributions of sea-ice algae and associated variables, for example, chl a and DOC concentrations (Smith et al. 1997). In this study, both sea-ice chl $a$ and DOC concentrations were highest under low snow cover. It was expected that bacterial abundances would follow a similar pattern, since sea-ice bacterial abundances have been significantly correlated with chl $a$ and DOC concentrations (Smith et al. 1989, Bunch \& Harland 1990, Gradinger et al. 1999b, Junge et al. 2004). Interestingly, in the present study, sea-ice bacterial abundances were not significantly different between high and low snow cover, even with higher chl $a$ and DOC concentrations under low snow cover 
(Table 1, Fig. 4A,B). Here we discuss the potential use of different carbon sources by sea-ice bacteria and the role of protozoan bacterivory in shaping the observed seasonal and spatial patterns in bacterial abundance.

\section{DOC and EPS}

As observed in a previous study of landfast sea ice of Resolute Passage (Smith et al. 1997), seasonal trends in sea-ice DOC concentrations paralleled those in sea-ice algal biomass, with a rapid increase in DOC concentrations following the onset of the sea-ice algal bloom, especially under low snow cover (3 April, Fig. 2A). The significant correlations between DOC and chl a concentrations, under high and low snow cover, indicate that sea-ice algae are significant contributors to sea-ice DOC concentrations (Fig. 2C).

Sea ice and surface waters on the Mackenzie Shelf contained high concentrations of DOC, with values being, on average, 7 times higher than DOC concentrations in mixed shelf waters of the Arctic Ocean (0 to $25 \mathrm{~m}$ average $34.4 \pm 4.0(1 \mathrm{SD}) \mu \mathrm{M}$, Wheeler et al. 1997). During our study, DOC concentrations at the ice-water interface were similar to sea-ice DOC concentrations under low snow cover. However, unlike sea ice, surface water DOC concentrations were not correlated with surface water chl a concentrations. Low surface water chl a concentrations and the lack of coupling between surface water DOC and chl a concentrations indicate that DOC may have been released from the sea ice to the interfacial waters, resulting in the high surface water DOC concentrations observed during this study.

EPS represent a carbon-rich substrate, and algae, particularly diatoms, are suggested to be the major producers of EPS within the sea ice (Krembs \& Engel 2001, Meiners et al. 2003, Riedel et al. 2006). Our results suggest that similar processes are involved in the algal production of sea-ice DOC and EPS, as indicated by the significant correlations between DOC and EPS-carbon concentrations under high and low snow cover (Fig. 2D). Due to methodological procedures, DOC (filtered through $0.7 \mu \mathrm{m}$ nominal pore size) and EPS (retained on $0.4 \mu \mathrm{m}$ filters) operationally overlapped within a narrow range of particle sizes $(0.4$ to $0.7 \mu \mathrm{m})$ in this study. However, DOC and EPS are expected to represent essentially different types of particles, since the method used for measuring EPS concentrations specifically applies to acidic polysaccharides (Passow \& Alldredge 1995), while DOC measurements include all types of organic matter within its size range.

Interactions between bacteria and algal-derived carbon sources (i.e. both DOC and EPS) in the sea ice likely explain the significant correlations between large-sized bacterial and autotrophic abundances (Fig. 5A,B) and the presence of large, diatom-attached bacteria in the sea ice. Although DOC is recognized as the main carbon source for bacterial production, EPS has also been suggested to enhance bacterial growth by providing a carbon-rich substrate or by favoring bacterial attachment to particles in the sea ice (Meiners et al. 2004) and water column (i.e. marine snow, Müller-Niklas et al. 1994). In our study, sea-ice bacterial abundances were significantly correlated with DOC concentrations under low snow cover only. However, partial correlation analyses indicated multiple intercorrelations between total bacterial abundances, DOC, EPS-carbon and chl a concentration such that there was no clear evidence of a preferred bacterial carbon source or preferred site of attachment.

\section{Grazing activity}

Sea-ice heterotrophs on the Mackenzie Shelf removed, on average, $57 \% \mathrm{~d}^{-1}$ (high and low snow sites combined) of large-sized bacterial abundances and $53 \%$ of estimated large-sized bacterial production. Our community grazing rates and estimates of bacterial production were within a similar range of values from marine studies in polar regions (Anderson \& Rivkin 2001, Vaqué et al. 2004, Wells \& Deming 2006). However, our results were, on average, higher than bacterivory rates estimated from short-term FLB uptake experiments from the sea ice (average $36 \% \mathrm{~d}^{-1}$ of total bacterial standing stocks) in Saromako lagoon, Okhotsk Sea (Sime-Ngando et al. 1999), and our maximum grazing rates were higher than those observed in the upper water column of the central Arctic Ocean (maximum $46 \times 10^{6}$ bacteria $\mathrm{l}^{-1} \mathrm{~d}^{-1}$, Sherr et al. 1997).

Experimental studies have shown that grazing rates may be overestimated due to the potential preference of protists for larger-sized prey (Sherr \& Sherr 1993). In our study, large-sized bacteria were a significant component of natural bacterial assemblages, representing up to $76 \%$ of total sea-ice bacterial abundances (Table 1, Fig. 4). Thus we expect if any preferential selection for large-sized bacteria had occurred, it would have also taken place under natural conditions. We are therefore confident that our community grazing rates represent actual values in the sea ice.

Despite evidence of grazing activity throughout our study, there was only a weak indication of net heterotrophic $\mathrm{NH}_{4}$ regeneration in the sea ice. On the Mackenzie Shelf, $\mathrm{NH}_{4}$ regeneration was measured (average $0.48 \mu \mathrm{M} \mathrm{d}^{-1}$ ) in newly formed sea ice which 
had sea-ice heterotrophic abundances an order of magnitude lower than in this study (Riedel et al. 2007). Therefore, we expected that $\mathrm{NH}_{4}$ regeneration would also be occurring during this study as a result of increased heterotrophic abundance and grazing activity. The lack of detectable net $\mathrm{NH}_{4}$ regeneration indicates concurrent dark uptake of $\mathrm{NH}_{4}$ by sea-ice bacteria and possibly algae during the present study. Dark $\mathrm{NH}_{4}$ uptake by bacteria and algae was also apparent in the newly formed sea ice on the Mackenzie Shelf (Riedel et al. 2007).

Community grazing rates (Fig. 6A) and estimated bacterial production rates were not significantly higher in sea ice under low snow, as compared to high snow cover, despite apparent enhanced bacterial growth conditions under low snow cover (e.g. higher DOC and EPS-carbon concentrations, Fig. 2). This suggests that sea-ice DOC concentrations, under high and low snow cover, were in excess of bacterial carbon requirements. Inorganic nutrients may have limited bacterial production under low snow cover where sea-ice chl $a$ and DOC concentrations were highest. However, in a concurrent study (authors' unpubl. data) sea-ice dissolved inorganic nitrogen concentrations were not significantly different between high and low snow cover, and sea-ice $\mathrm{PO}_{4}$ concentrations under low snow cover were actually higher than under high snow cover. Thus, we suggest that bacterivory is a key factor controlling bacterial abundances within the sea ice. However, factors such as viral lysis, temperature and the release of bacteria to surface waters could also influence seaice bacterial abundances.

\section{Ingestion rates}

Ingestion rate estimates take into account cell abundances. Therefore, ingestion rates can be overestimated if specific groups (e.g. ciliates) or sizes (e.g. tiniest heterotrophs) are omitted from cell counts. In our study, sea-ice ciliates were not enumerated. However, a concurrent study showed that sea-ice ciliate abundances were low (average $<1 \%$ of sea-ice protist abundances, M. Różańska pers. comm.), at the same study site. In addition, our cell counts (Fig. 3) are within a similar range of nano-protist and heterotrophic microprotist counts from first-year Arctic sea-ice (Laurion et al. 1995, Sime-Ngando et al. 1997) and thus, we do not believe that our cell counts were underestimated. All together this indicates that our ingestion rates were not overestimated.

Heterotrophic ingestion rates of large-sized bacteria in the sea ice during this study (Fig. 6B) were within a similar range as heterotrophic nanoflagellate (i.e. $<20 \mu \mathrm{m}, \mathrm{HNAN}$ ) ingestion rates (72 to 1536 bacteria
HNAN $^{-1} \mathrm{~d}^{-1}$ ) from first-year sea ice of Resolute Passage during the spring sea-ice algal bloom (Laurion et al. 1995). In the Resolute study, the FLB used were 1 to $2 \mu \mathrm{m}$, indicating that the HNAN were also consuming large-sized, sea-ice bacteria. In the first-year sea ice of Resolute Passage the large-sized bacteria ranged in size between 1 and $5 \mu \mathrm{m}$ (Laurion et al. 1995). It is well established that nano-sized grazers are important contributors to marine bacterivory, including bacterivory in the Arctic Ocean (Sherr et al. 1997, Strom 2000). It was evident in our study that nano-sized protists were also actively consuming the large-sized bacteria, as we did not observe heterotrophic protist cells $>20 \mu \mathrm{m}$ in $30 \%$ of the grazing experiments where bacterivory was detected.

Ingestion rates (Fig. 6B, Table 2) were lower during the sea-ice algal bloom period as compared to the prebloom period, despite increasing abundances of total and large-sized bacteria during the bloom period (Fig. 4A,B). We propose that increased EPS concentrations during the sea-ice algal bloom (Riedel et al. 2006) contributed to lower heterotrophic ingestion rates by interfering with heterotrophic grazing activity, as evidenced by the significant negative correlations between ingestion rates and EPS-carbon concentrations under high and low snow cover (Fig. 7B). Heterotrophic protist ingestion rates have been shown to be inversely correlated with the concentration of transparent exopolymer particles (TEP) under experimental conditions (Mari \& Rassoulzadegan 2004). For example, high concentrations of exopolymers can decrease grazing rates of herbivorous (Liu \& Buskey 2000) and bacterivorous (Mari \& Rassoulzadegan 2004) ciliates. High concentrations of EPS within the sea ice may interfere with the mobility and feeding of heterotrophs by coating or clogging feeding appendages (Liu \& Buskey 2000), thereby decreasing ingestion rates.

\section{Carbon sources for heterotrophic protists}

The consumption of large-sized bacteria provided the minimal carbon requirements for the observed net population growth of sea-ice heterotrophs prior to the sea-ice algal bloom (Table 2). During the sea-ice algal bloom, it is evident that additional carbon sources were required for heterotrophic protist growth, as was also observed in Arctic sea ice by Laurion et al. (1995) and Sime-Ngando et al. (1999).

Our results provide evidence that the growth of heterotrophs in the sea-ice of Arctic shelves involves multiple carbon sources. We recognize that several carbon sources, in addition to large-size bacteria, could have potentially been used by heterotrophs during this study including (1) consumption of small-sized and 
attached bacteria (Caron 1987), (2) consumption of algal cells or other heterotrophic protists (Sherr \& Sherr 2002, Michel et al. 2002), (3) direct utilization of EPS (Sherr 1988, Tranvik et al. 1993), and possibly (4) direct utilization of DOC or DOC adsorbed to EPS (Decho \& Lopez 1993). During our study, the consumption of diatoms, which were abundant within the seaice, was directly observed in the largest (ca. $130 \times$

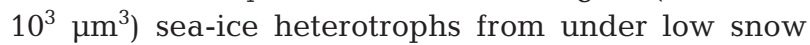
cover only. The negative correlations between ingestion rates and both DOC and EPS-carbon concentrations (Fig. 7A,B) may also suggest that during the seaice algal bloom, DOC and/or EPS could be used as a protist carbon source in addition to or instead of bacteria, thereby decreasing ingestion rates. The high concentrations of DOC and EPS during the sea-ice algal bloom period may facilitate the use of DOC and/or EPS by the heterotrophs. However, the separate contribution of DOC and EPS to heterotrophic carbon requirements can not be determined due to the significant intercorrelation between DOC and EPS concentrations (Fig. 2D). Further study is needed to verify the direct uptake of EPS and any associated organic matter by sea-ice heterotrophs.

\section{CONCLUSIONS}

Mackenzie Shelf sea ice and associated surface waters are carbon-rich environments supporting high bacterial abundances and the growth of large-sized bacteria. Bacterial abundances and heterotrophic bacterivory are closely linked to the concentrations of DOC, EPS and chl $a$, although intercorrelations among the variables limit our ability to discern direct relationships.

Our study describes an active heterotrophic microbial food web within the sea ice on the Mackenzie Shelf, which persisted throughout the sea-ice algal pre-bloom and bloom period. Bacterial and heterotrophic protist abundances and rates of bacterivory appear to be relatively consistent regardless of differences in snow cover, which strongly affect chl $a$ and EPS concentrations. Heterotrophic bacterivory was an important source of bacterial mortality and contributed significantly to the carbon requirements of the sea-ice heterotrophs prior to the sea-ice algal bloom. To meet the carbon requirements of heterotrophs during the sea-ice algal bloom, alternative carbon sources such as EPS may have been used, in addition to bacteria and algal cells. It is evident that complex microbial food webs are associated with first-year sea ice and that DOC and EPS are integral components of heterotrophic processes within the sea-ice and surface waters of Arctic shelves.
Acknowledgements. We sincerely thank the officers and crew of the CCGS 'Amundsen' for their support. B. LeBlanc, T. Juul-Pedersen, M. Różańska, A. Tatarek, J. Wiktor, and other collaborators assisted in the field and laboratory during the expedition. K. Junge and J. Deming supplied the sea-ice bacteria culture. B. LeBlanc and C. Belzile conducted the DOC and flow cytometry analyses, respectively. We also thank 3 reviewers for their insightful comments which improved this manuscript. This project was supported by grants from the Natural Sciences and Engineering Research Council (NSERC) of Canada (Research Network grant to C.M. and M.G.; Individual and Northern Research Supplement Discovery grants to M.G.) and from the Department of Fisheries and Oceans (DFO) Academic Science Subvention Program to M.G. and C.M., and from the Science Strategic Fund to C.M. Partial operating funds for the CCGS 'Amundsen' were provided by the International Joint Ventures Fund of the Canada Foundation for Innovation and the Fonds québécois de la recherche sur la nature et les technologies (FQRNT). A.R. received post-graduate scholarships from NSERC, UQAR, the Fondation de l'UQAR and the Institut des sciences de la mer de Rimouski (ISMER), and financial support from Indian and Northern Affairs Canada for fieldwork. This is a contribution to the research programs of the Canadian Arctic Shelf Exchange Study (CASES), the Freshwater Institute (Fisheries and Oceans Canada), ISMER and Québec-Océan.

\section{LITERATURE CITED}

Anderson MR, Rivkin RB (2001) Seasonal patterns in grazing mortality of bacterioplankton in polar oceans: a bipolar comparison. Aquat Microb Ecol 25:195-206

Azam F, Fenchel T, Field JG, Gray JS, Meyer-Reil LA, Thingstad F (1983) The ecological role of water-column microbes in the sea. Mar Ecol Prog Ser 10:257-263

Bower CE, Holm-Hansen T (1980) A salicylate-hypochlorite method for determining ammonia in seawater. Can J Fish Aquat Sci 37:794-798

Bunch JN, Harland RC (1990) Bacterial production in the bottom surface of sea ice in the Canadian subarctic. Can J Fish Aquat Sci 47:1986-1995

Caron DA (1987) Grazing of attached bacteria by heterotrophic microflagellates. Microb Ecol 13:203-218

Decho AW, Lopez GR (1993) Exopolymer microenvironments of microbial flora: Multiple and interactive effects on trophic relationships. Limnol Oceanogr 38:1633-1645

Engel A (2004) Distribution of transparent exopolymer particles (TEP) in the northeast Atlantic Ocean and their potential significance for aggregation processes. DeepSea Res I 51:83-92

Garneau MĖ, Vincent WF, Alonso-Sáez L, Gratton Y, Lovejoy C (2006) Prokaryotic community structure and heterotrophic production in a river-influenced coastal arctic ecosystem. Aquat Microb Ecol 42:27-40

Garrison DL, Buck KR (1986) Organism losses during ice melting: a serious bias in sea ice community studies. Polar Biol 6:237-239

Gosselin M, Legendre L, Therriault JC, Demers S, Rochet M (1986) Physical control of the horizontal patchiness of seaice microalgae. Mar Ecol Prog Ser 29:289-298

Gowing MM, Garrison DL, Gibson AH, Krupp JM, Jeffries MO, Fritsen $\mathrm{CH}$ (2004) Bacterial and viral abundance in Ross Sea summer pack ice communities. Mar Ecol Prog Ser 279:3-12

Gradinger R, Zhang Q (1997) Vertical distribution of bacteria 
in Arctic sea ice from the Barents and Laptev Seas. Polar Biol 17:448-454

Gradinger R, Friedrich C, Spindler M (1999a) Abundance, biomass and composition of the sea ice biota of the Greenland Sea pack ice. Deep-Sea Res II 46:1457-1472

Gradinger R, Friedrich C, Weissenberger J (1999b) On the structure and development of Arctic pack ice communities in Fram Strait: a multivariate approach. Polar Biol 12: 727-733

Grossmann S, Dieckmann GS (1994) Bacterial standing stock, activity, and carbon production during formation and growth of sea ice in the Weddell Sea, Antarctica. Appl Environ Microbiol 60:2746-2753

Hansen PJ, Bjørnsen PK, Hansen BW (1997) Zooplankton grazing and growth: Scaling within the $2-2,000-\mu \mathrm{m}$ body size range. Limnol Oceanogr 42:687-704

Hillebrand H, Dürselen CD, Kirschtel D, Pollingher U, Zohary $T$ (1999) Biovolume calculation for pelagic and benthic microalgae. J Phycol 35:403-424

Horner R, Schrader GC (1982) Relative contributions of ice algae, phytoplankton, and benthic microalgae to primary production in nearshore regions of the Beaufort Sea. Arctic 35:485-503

Ikävalko J, Gradinger R (1997) Flagellates and heliozoans in the Greenland Sea ice studied alive using light microscopy. Polar Biol 17:473-481

Junge K, Imhoff F, Staley T, Deming JW (2002) Phylogenetic diversity of numerically important Arctic sea-ice bacteria cultured at subzero temperatures. Microb Ecol 43: $315-328$

Junge $\mathrm{K}$, Eicken H, Deming JW (2004) Bacterial activity at -2 to $-20^{\circ} \mathrm{C}$ in Arctic wintertime sea ice. Appl Environ Microbiol 70:550-557

Kaartokallio H (2004) Food web components, and physical and chemical properties of Baltic sea ice. Mar Ecol Prog Ser 273:49-63

Krembs C, Engel A (2001) Abundance and variability of microorganisms and transparent exopolymer particles across the ice-water interface of melting first-year sea ice in the Laptev Sea (Arctic). Mar Biol 138:173-185

Laurion I, Demers S, Vézina AF (1995) The microbial food web associated with the ice algal assemblage: biomass and bacterivory of nanoflagellate protozoans in Resolute Passage (high Canadian Arctic). Mar Ecol Prog Ser 120: $77-87$

Liu H, Buskey EJ (2000) The exopolymer secretions (EPS) layer surrounding Aureoumbra lagunensis cells affects growth, grazing, and behavior of protozoa. Limnol Oceanogr 45:1187-1191

Maranger R, Bird DF, Juniper SK (1994) Viral and bacterial dynamics in Arctic sea ice during the spring algal bloom near Resolute, N.W.T., Canada. Mar Ecol Prog Ser 111: 121-127

Mari X, Rassoulzadegan F (2004) Role of TEP in the microbial food web structure. I. Grazing behavior of a bacterivorous pelagic ciliate. Mar Ecol Prog Ser 279:13-22

Meiners K, Gradinger R, Fehling J, Civitarese G, Spindler M (2003) Vertical distribution of exopolymer particles in sea ice of the Fram Strait (Arctic) during autumn. Mar Ecol Prog Ser 248:1-13

Meiners K, Brinkmeyer R, Granskog MA, Lindfors A (2004) Abundance, size distribution and bacterial colonization of exopolymer particles in Antarctic sea ice (Bellingshausen Sea). Aquat Microb Ecol 35:283-296

Menden-Deuer S, Lessard EJ (2000) Carbon to volume relationships for dinoflagellates, diatoms, and other protist plankton. Limnol Oceanogr 45:569-579
Michel C, Legendre L, Ingram RG, Gosselin M, Levasseur M (1996) Carbon budget of sea-ice algae in spring: evidence of a significant transfer to zooplankton grazers. J Geophys Res 101:18345-18360

Michel C, Nielsen TG, Nozais C, Gosselin M (2002) Significance of sedimentation and grazing by ice micro- and meiofauna for carbon cycling in annual sea ice (northern Baffin Bay). Aquat Microb Ecol 30:57-68

Müller-Niklas G, Schuster S, Kaltenboeck E, Herndl GJ (1994) Organic content and bacterial metabolism in amorphous aggregations of the northern Adriatic Sea. Limnol Oceanogr 39:58-68

Mundy CJ, Barber DG, Michel C (2005) Variability of snow and ice thermal, physical and optical properties pertinent to sea ice algae biomass during spring. J Mar Syst 58: $107-120$

Norland S (1993) The relationship between biomass and volume of bacteria. In: Kemp PF, Sherr BF, Sherr EB, Cole JJ (eds) Handbook of methods in aquatic microbial ecology. Lewis Publications, Boca Raton, FL, p 303-307

Parsons TR, Maita Y, Lalli CM (1984) A manual of chemical and biological methods for seawater analysis. Pergamon Press, Toronto

Passow U, Alldredge AL (1995) A dye-binding assay for the spectrophotometric measurement of transparent exopolymer particles (TEP). Limnol Oceanogr 40:1326-1335

Renaud PE, Riedel A, Michel C, Morata N, Gosselin M, JuulPedersen T, Chiuchiolo A (2007) Seasonal variation in benthic community oxygen demand: A response to an ice algal bloom in the Beaufort Sea, Canadian Arctic? J Mar Syst $67: 1-12$

Riedel A, Michel C, Gosselin M (2006) Seasonal study of seaice exopolymeric substances on the Mackenzie Shelf: implications for the transport of sea-ice bacteria and algae. Aquat Microb Ecol 45:195-206

Riedel A, Michel C, Gosselin M, LeBlanc B (2007) Enrichment of nutrients, exopolymeric substances and microorganisms in newly formed sea ice on the Mackenzie shelf. Mar Ecol Prog Ser 342:55-67

Rysgaard S, Kühl M, Glud RN, Würgler Hansen J (2001) Biomass, production and horizontal patchiness of sea ice algae in a high-Arctic fjord (Young Sound, NE Greenland). Mar Ecol Prog Ser 223:15-26

Salat J, Marrasé C (1994) Exponential and linear estimations of grazing on bacteria: effects of changes in the proportion of marked cells. Mar Ecol Prog Ser 104:205-209

Sherr EB (1988) Direct use of high molecular weight polysaccharides by heterotrophic flagellates. Nature 335: 348-351

Sherr EB, Sherr BF (1993) Protistan grazing rates via uptake of fluorescently labeled prey. In: Kemp PF, Sherr BF, Sherr EB, Cole JJ (eds) Handbook of methods in aquatic microbial ecology. Lewis Publications, Boca Raton, FL, p 695-701

Sherr EB, Sherr BF (2002) Significance of predation by protists in aquatic microbial food webs. Antonie Leeuwenhoek 81:293-308

Sherr EB, Caron DA, Sherr BF (1993) Staining of heterotrophic protists for visualization via epifluorescence microscopy. In: Kemp PF, Sherr BF, Sherr EB, Cole JJ (eds) Handbook of methods in aquatic microbial ecology. Lewis Publications, Boca Raton, FL, p 213-227

Sherr EB, Sherr BF, Fessenden L (1997) Heterotrophic protists in the central Arctic Ocean. Deep-Sea Res II 44:1665-1682

Sherr BF, del Giorgio P, Sherr EB (1999) Estimating abundance and single-cell characteristics of respiring bacteria via the redox-dye CTC. Aquat Microb Ecol 18:117-131 
Sime-Ngando T, Gosselin M, Juniper SK, Levasseur M (1997) Changes in sea-ice phagotrophic microprotists (20-200 $\mu \mathrm{m})$ during the spring algal bloom, Canadian Arctic Archipelago. J Mar Syst 11:163-172

Sime-Ngando T, Demers S, Juniper SK (1999) Protozoan bacterivory in the ice and the water column of a cold temperate lagoon. Microb Ecol 37:95-106

Simon M, Azam F (1989) Protein content and protein synthesis rates of planktonic marine bacteria. Mar Ecol Prog Ser 51:201-213

Smith REH, Clement P (1990) Heterotrophic activity and bacterial productivity in assemblages of microbes from sea ice in the High Arctic. Polar Biol 10:351-357

Smith REH, Clement P, Cota GF (1989) Population dynamics of bacteria in Arctic sea ice. Microb Ecol 17:63-76

Smith REH, Gosselin M, Kudoh S, Robineau B, Taguchi S (1997) DOC and its relation to algae in bottom ice communities. J Mar Syst 11:71-80

Sokal RR, Rohlf FJ (1995) Biometry: the principles and practice of statistics in biological research, 3rd edn. WH Freeman, New York

Editorial responsibility: Urania Christaki, Wimereux, France
Strom SL (2000) Bacterivory: interactions between bacteria and their grazers. In: Kirchman DL (ed) Microbial ecology of the oceans. John Wiley \& Sons, New York, p 351-386

Thomas DN, Lara RJ, Eicken H, Kattner G, Skoog A (1995) Dissolved organic matter in Arctic multi-year sea ice during winter: major components and relationship to ice characteristics. Polar Biol 15:477-483

Tranvik LJ, Sherr EB, Sherr BF (1993) Uptake and utilization of 'colloidal DOM' by heterotrophic flagellates in seawater. Mar Ecol Prog Ser 92:301-309

Vaqué D, Agustí S, Duarte CM (2004) Response of bacterial grazing to experimental manipulation of an Antarctic coastal nanoflagellate community. Aquat Microb Ecol 36: $41-52$

Wells LE, Deming JW (2006) Significance of bacterivory and viral lysis in bottom waters of Franklin Bay, Canadian Arctic, during winter. Aquat Microb Ecol 43:209-221

Wheeler PA, Watkins JM, Hansing RL (1997) Nutrients, organic carbon and organic nitrogen in the upper water column of the Arctic Ocean: implications for the sources of dissolved organic carbon. Deep-Sea Res II 44:1571-1592

Submitted: December 5, 2006; Accepted: September 28, 2007 Proofs received from author(s): November 16, 2007 